\title{
3. The Circle of Songs: Traditional Song and the Musical Score to C. P. Mountford's Documentary Films
}

\author{
Anthony Linden Jones
}

This chapter interrogates the process of incorporation of traditional Aboriginal song $^{1}$ into the context of musical underscore ${ }^{2}$ for two documentary films using Western orchestral instrumentation. I contextualise these practices in the history of ethnographic film-making in Australia and contemporary film scoring practices up to the time of these films and examine the impact of the limitations of recording technology on film composers' interpretation of the songs. By placing the scores in their historical and cultural context and employing a range of analytic tools, I aim to consider how these acts of appropriation of culturally significant artefacts might be understood today.

Why should we concern ourselves with the musical underscore of a film, rather than just with the visual or narrative content? In Unheard Melodies (1987), Claudia Gorbman highlights the power of music to influence our engagement with the narrative of a film, made more powerful through its unconscious reception:

Every moviegoer, every film scholar, tin ear notwithstanding, becomes aware from time to time of the ubiquity and psychological power of music in dramatic films. Such moments of lucidity tend to occur when we take note of how shamelessly emotional or copious a film score has been: what has been blaring in the background the entire time suddenly comes to the foreground of consciousness. Suddenly the story is perceived to inhabit a world strangely replete with musical sound, rhythm, signification ... until, a few scenes or measures later, we drop off, become re-invested in the story again. Then the music is "working" once more, masking its own insistence and sawing away in the backfield of consciousness. ${ }^{3}$

\footnotetext{
1 For the purpose of this chapter, 'song' refers to accompanied or unaccompanied singing. In this instance, the traditional songs are captured in field recordings which thus represent a particular instantiation of a song, frozen in time.

2 The term 'underscore' relates to music placed under narration or dialogue in a film. The term is often used synonymously with 'score', but always relates to the music heard rather than the music on paper. Whereas 'score' can mean either the music heard or the music on paper. The melody of songs can be used as an influence in the composition of non-vocal underscore.

3 Claudia Gorbman, Unheard Melodies: Narrative film music (Bloomington: Indiana University Press, 1987), 1.
} 
Musical underscore mediates an emotional affiliation between the spectator and the characters and narrative of a film. By deconstructing the underscore, we can uncover an important element of the intended emotional communication of a film. This is especially relevant in the context of documentary film where music is used to unconsciously influence our engagement with real people and cultures.

Travelling with the 1948 American-Australian Expedition to Arnhem Land in the far north of Australia, expedition leader Charles P. Mountford and cameraman Peter Basset-Smith captured audio recordings and shot silent documentary footage of traditional Aboriginal song and ceremony, places, and wildlife. From the footage, three films were compiled with narration, sound effects, composed music and field recordings of traditional song: Aborigines of the Sea Coast, Birds and Billabongs, and Arnhem Land. The US cameraman Howell Walker also travelled with the Arnhem Land Expedition and shot footage for compilation into films to be produced by the National Geographic Society. For this present discussion, I shall consider only the Australian-produced films; 'Arnhem Land Expedition films' in this chapter should be taken here to refer to those films only.

For the composition of the musical underscore for the three sound films, Mountford called on the services of composers Alfred and Mirrie Hill. To inform them of the musical life of the Aboriginal people of Arnhem Land, Mountford organised for Alfred and Mirrie Hill to be supplied with a collection of field recordings of Aboriginal song. Inspired by the idea of incorporating Aboriginal song into the scores for the films, Alfred and Mirrie Hill transcribed a number of the songs. Their transcriptions feature significantly in the scores to two of the Arnhem Land Expedition films: Aborigines of the Sea Coast, ${ }^{4}$ and Arnhem Land. ${ }^{5}$

Before looking at the Arnhem Land Expedition films, I give a brief history of ethnographic filmmaking practice in Australia and the historical events that shaped its path. Included is a discussion of the artistic movement of the Jindyworobaks in literature and in music. After detailing the background to the establishment of the Arnhem Land Expedition, I focus on the use of traditional song as inspiration for the composition of scores to the two Arnhem Land Expedition films.

\footnotetext{
4 The film is named in different archives as either Aborigines of the Sea Coast, or Aborigines of the Seacoast. Mountford, Charles P. Aborigines of the Sea Coast. (Lindfield: Film Australia, 1951). Preservation copies of both the original film of 1950 and an edited version made in 1973 are held in different formats under the same title number at the National Film and Sound Archive of Australia (NFSA). Mountford, C.P., dir. 'Aborigines of the Seacoast', Film Australia Collection, title no. 54, NFSA, Canberra, 1950.

5 Also referred to in correspondence as The Natural History of Arnhem Land, or Expedition to Arnhem Land. This last was also the title for a radio documentary produced by Colin Simpson of the Australian Broadcasting Commission. The film is held in preservation copies: Mountford, C.P., 'Arnhem Land', Film Australia Collection, title no. 703, NFSA, Canberra, 1950.
} 


\section{Ethnographic Film and Nationalism in Australia}

Soon after the development of moving pictures at the end of the nineteenth century, storytellers and adventurers in Australia quickly recognised the potential of the technology to allow the creation of uniquely Australian stories and capture on film elements of Australian life, beginning with the story films produced by the Limelight Department of the Salvation Army in Melbourne. ${ }^{6}$ However, the value of film as a tool for anthropological study took some time to establish. Although some of the earliest ethnographic films had been made in Australia-Alfred Cort Haddon's films of the Mer people of the Torres Strait Islands in 1898, and Baldwin Spencer's central Australian films of 1901 and of Arnhem Land in 1912 - there was a reluctance by the academic anthropological community in those early decades to trust in the veracity of film as an ethnographic record. ${ }^{7}$ However, a growing awareness of the uniqueness and variety of Aboriginal Australian cultures, generally considered doomed to imminent demise ${ }^{8}$ heightened a sense of urgency to capture records of what remained, drawing researchers of the University of Adelaide to make a significant body of films through the 1930s. ${ }^{9}$

Five days after the outbreak of the war in Europe, on 8 September 1939 the Australian federal government formed the Department of Information (DOI) to establish control over the flow of information in a time of international conflict. Soon thereafter, the Film Division was formed as a division of the DOI tasked to commission film production as part of the war effort. ${ }^{10}$ The isolation imposed by the remoteness of the continent from Great Britain during the conflict, and Australia's engagement in the conflict in the Pacific, served to foster a sense of independent nationhood. ${ }^{11}$ The artistic community in Australia began to look at those elements which marked a differentiation from Europe, making tentative steps towards the celebration of Aboriginal culture.

In April 1945, one month before the surrender of Germany in Europe, the Australian National Film Board was established and tasked to expand, promote and coordinate Australian documentary, educational and instructional films for

\footnotetext{
6 Graham Shirley and Brian Adams, Australian Cinema, The first eighty years (Sydney: Currency Press, 1989), 10.

7 Alison Margaret Griffiths, Origins of Ethnographic Film (PhD, New York University, 1998), 4.

8 This perception was highlighted by the writings of amateur ethnologist Daisy Bates, among others, as discussed at length in the book: Bob Reece, Daisy Bates: Grand dame of the desert, ed. Carol Natsis (Canberra: National Library of Australia, 2007).

9 Ian Dunlop, 'Ethnographic Filmmaking in Australia: The first seventy years (1898-1968)', Studies in Visual Communication 9:1 (1983): 12.

10 Graham Shirley, Manager: Access Projects, NFSA, private communication, 26 February 2013; National Archives of Australia. 'Commonwealth Film Unit: Fact sheet 25', (2013), accessed 12 February 2013, http:// www.naa.gov.au/collection/fact-sheets/fs25.aspx

11 Geoffrey Blainey, The Tyranny of Distance: How distance shaped Australia's history (Sydney: Macmillan, 2001).
} 
exhibition in Australia and abroad. The DOI was the instrument of the Board in production, and was responsible to the Board, while the National Library was its instrument in the acquisition and distribution of films.

In 1950, the Menzies Government dissolved the DOI and control of the Film Division was transferred to the Australian News and Information Bureau (ANIB). In 1973, the Whitlam Government created the Department of Media, to which the Film Division was again transferred, and soon renamed Film Australia. In 2008, Film Australia was absorbed into the government film funding and advocacy body Screen Australia. On 1 July 2011, the Film Australia collection, a collection of over 5,000 films, was transferred from Screen Australia into the holdings of the National Film and Sound Archives of Australia in Canberra. ${ }^{12}$

Although the technology to record synchronised sound for film had first appeared in the late 1920s, the equipment required for sound was bulky and expensive, had significant power requirements and stringent operational limits for temperature and humidity, which was not practical for ethnographic field recording. Until that time, with the exception of big studio films, films would be filmed silent, with sound applied in 'post-production' ${ }^{13}$ It would not be until the development of lightweight tape recording with the capability for synchronisation to film in the 1960s that recording of synchronised sound for film in remote locations would be feasible.

By the time of the production of the Arnhem Land Expedition films, synchronised sound in film had been available for a little over twenty years, yet the conventions of film music had been established and reaffirmed through another earlier forty years of musical accompaniment to silent film. The films made in the Hollywood studio system from the beginning of the twentieth century became the technical and aesthetic standard against which most other national cinema practices were measured. As a result, a number of filmmaking conventions were established as an 'institutional practice for the regulation of nondiegetic music in film', ${ }^{14}$ such as the idea that music for a film should fill all the gaps between sound effects and dialogue so as to banish silence, and that the music should use Western orchestral instruments and be usually written in a late-nineteenth century Romantic style. ${ }^{15}$ The wider community in Australia had had very little exposure to traditional Aboriginal song and instrumentation, and the perceived 'alien'

\footnotetext{
12 National Archives of Australia. 'Commonwealth Film Unit: Fact sheet 25', (2013), accessed 12 February 2013, http://www.naa.gov.au/collection/fact-sheets/fs25.aspx.

13 James McCarthy, retired Music Officer of Film Australia, personal communication, 17 February 2013.

14 Diegetic music is that which appears to come from within the scene and that the characters on screen can be assumed to hear. Nondiegetic music is therefore music external to the scene, such as musical underscore applied later. Kathryn Kalinak, Settling the Score: Music and the classical Hollywood film, (Madison: University of Wisconsin Press, 1992), xiv.

15 A number of complementary explanations have been offered as to why this should be so. See Caryl Flinn, Strains of Utopia: Gender, nostalgia and Hollywood film music, (Princeton: Princeton University Press, 1992),
} 
and 'primitive' nature of the music would have made the idea of a Western score based primarily on traditional song almost unthinkable in the context of a film intended for public non-specialist viewing. The documentary films in this study were intended to entertain as much as to inform, and so conventional processes of musical accompaniment were expected without question.

In the late 1930s, an artistic movement had formed in literature, the Jindyworobaks - a term coined by poet Rex Ingamells in a credo he published in 1938, from a Woiwurrung word for 'to join'. The Jindyworobaks took as their inspiration aspects of the language and stories of Aboriginal culture, yet were working in idioms taken from the European culture from which they hoped to distance themselves. ${ }^{16}$ In subsequent decades, a number of composers of music became interested in incorporating aspects of traditional Aboriginal culture and language into their composition practice. The practices of these composers have retrospectively been compared to the Jindyworobaks, even though they did not identify themselves as part of a coherent group. ${ }^{17}$ Composers usually identified with this approach include Alfred and Mirrie Hill, Clive Douglas, John Antill, Margaret Sutherland, James Penberthy, and Peter Sculthorpe. In addition to composing concert music, most of these composers had an involvement with the composition of music for documentary films as a way of securing an income. With the exception of Peter Sculthorpe in the final decade of his life, these composers appear to have been less concerned to engage with Aboriginal people in the making of music than to create their own filtered view of Aboriginalityseen as a source of influence to colour or exoticise European processes of music making. While for the most part these composers were content to draw only from language and stories in the creation of their 'Aboriginal' works, there were a few who would go further and incorporate elements of Aboriginal traditional song, taking the suggestion from Henry Tate, writing in 1924:

Aboriginal music is surprisingly interesting. Wild and barbaric as much of it sounds, it is rich in rhythms and themes that, once annotated and fixed, will supply a copious reservoir of melodic gems and rhythmical fragments of the type that composers all over the world are continually seeking. ${ }^{18}$

\footnotetext{
4; Mark Slobin, 'The Steiner Superculture', in Global Soundtracks: Worlds of film music, ed. Mark Slobin (Middleton: Wesleyan University Press, 2008), 12; Anahid Kassabian, Hearing Film: Tracking identifications in contemporary Hollywood film music (New York: Routledge, 2001), 58.

16 The movement is detailed in David Symons, 'The Jindyworobak Connection in Australian Music, c. 1940-1960', Context: Journal of music research 23 (2002): 35.

17 Symons debates the suitability of this term to composers in Symons, 'The Jindyworobak Connection': 47.

18 Quoted in Christine Mercer, 'Henry Tate: Views on the artistic possibilities of Aboriginal music', in Encounters: Meetings in Australian music: Essays, images, interviews, eds Vincent Plush, Huib Schippers and Jocelyn Wolfe (Brisbane: Queensland Conservatorium Research Centre, 2005): 23.
} 
What spurred Alfred and Mirrie Hill on to engaging with Aboriginal song is not certain. Alfred had certainly been interested in Māori culture in New Zealand, although his engagement to write the score to the film Adventures in Maoriland was terminated in 1930 because of a disagreement with the Hollywood director Alexander Markey. ${ }^{19}$ Alfred and Mirrie Hill were aware of John Antill's ballet Corroboree, although Mirrie states that they did not see a performance of the ballet until the Beth Dean production of $1954 .{ }^{20}$ John Antill had been a composition student of Alfred's at the NSW Conservatorium of Music, and Alfred and Mirrie were friends of the conductor Eugene Goossens, so it is likely they would have heard a performance of the concert suite of Corroboree and may also have seen the score. Their first introduction to genuine Australian Aboriginal music might have been through the act of writing for Mountford's films, and for both composers, the fascination would not be long sustained. Each wrote only a small number of pieces using Aboriginal song over the next couple of years. In the early 1960s, after the death of Alfred, Mirrie Hill did set a number of poems written by Dame Mary Gilmore (a poet associated with the Jindyworobak movement) under the title Aboriginal Themes, but in this instance she chose not to use Aboriginal song as source material.

\section{Mountford's Ethnographic Films}

Conducting expeditions to central Australia in 1940 and 1942, South Australian amateur ethnologist Charles P. Mountford made the films Brown Men and Red Sand/Walkabout and Brown Men and Blue Mountains/Tjurunga. In creating an underscore for the films, an assortment of 'production' or 'library' music was used - no music was purpose-written for the film. ${ }^{21}$ The production music provides a buffer between phrases of Mountford's own narration but bears little relevance to the images or the narration. A couple of the production music clips used in the film exhibit characteristic musical stereotypes of the kind typically used at that time in Hollywood films to represent North American First

\footnotetext{
19 Peter Limbrick, Making Settler Cinemas: Film and colonial encounters in the United States, Australia and New Zealand (New York: Palgrave Macmillan, 2010), 153.

20 Mirrie Hill, 'Mirrie Hill Interviewed by Hazel De Berg' in Hazel De Berg Collection, National Library of Australia, Canberra, 10 June 1975, henceforth De Berg Interview.

21 Even before the technology for synchronisation of sound and film was developed in the late 1920s, British and US music publishing companies were producing and promoting libraries of printed or recorded music intended for use either with specific films or for general synchronisation in different end-uses. The recorded 'production' or 'library' music would be available on $78 \mathrm{rpm}$ discs for individual purchase or regular subscription by film or radio producers or other potential clients. To use this music, clients would pay a licensing fee dependent on the type of use and the size of the territory to be covered.
} 
Nations peoples - for example, grunting ostinato figures, harmonic intervals of parallel fourths, and pentatonic scales. ${ }^{22}$ These musical stereotypes bear little resemblance to any traditional Australian Aboriginal music.

Mountford used these two films as the basis of a successful series of lectures in Australia in 1945. Looking for opportunities to strengthen relationships between Australia and the US, the Australian government sent Mountford to conduct lecture tours there. While in the US, Mountford was able to begin discussions with the National Geographic Society and, through them, the Smithsonian Institution on the possibility of a cooperative expedition to Arnhem Land. These discussions culminated in the formation of the Arnhem Land Expedition, as a partnership between with the Australian government, the National Geographic Society, and the Smithsonian Institution. ${ }^{23}$

On his return in 1946, Mountford acted as an advisor on the Film Division production of the film Namatjira, the Painter (1946) directed by Stanley Hawes. The musical underscore for the film is quite indifferent to the subject matter of the film, but was not unusual for documentary music of the time. For this film, the brilliant young nineteen-year-old composer/conductor Charles Mackerras, having just completed a score for the short Film Division documentary Watch Over Japan (1946), was commissioned to write a score incorporating a surprisingly large orchestra. Unfortunately, although Mackerras' score is a wonderful piece of music in its own right, his orchestration was too big for the film, and was not written to leave space for the narration. As James McCarthy, the Music Officer of the Film Division/Film Australia describes: 'The commentary always came last, so the composers hadn't a hope of adjusting to it. The Canberra bureaucrats ... always wanted the last word, right up to the last minute. ${ }^{24}$ We are left with the unintentionally amusing result that at climactic points in the music, the volume is suddenly reduced to allow the narrator's voice to come through. I have found no evidence that Mackerras had considered making reference to Aboriginal music in the score. The primary influences on the music in his score were post-Romantic European composers.

\footnotetext{
22 See examples in Michael V. Pisani, Imagining Native America in Music (New Haven: Yale University Press, 2005).

23 For a précis on the establishment of the Arnhem Land Expedition and its political significance, see Martin Thomas, 'A Short History of the 1948 Arnhem Land Expedition', Aboriginal History 34 (2010): 143-73. 24 James McCarthy, personal communication, 21 February 2013.
} 


\section{Film and Audio Recordings from the Arnhem Land Expedition}

Martin Thomas describes the Arnhem Land Expedition as 'the last of the big expeditions', representing the end of an era of conquest. ${ }^{25}$ An international collaboration between Australia and the United States, the Arnhem Land Expedition party included researchers and support staff from the two countries, specialists in various flora and fauna as well as anthropology, Aboriginal art and cultural practice. DOI cinematographer Peter Bassett-Smith travelled with the Arnhem Land Expedition to document in film the findings of the researchers at three different sites in Arnhem Land in the far north of Australia.

Unsynchronised sound was recorded using a wire recorder and an omnidirectional dynamic microphone. ${ }^{26}$ These represented a much better quality than direct-to-disc recording, but had their own technical limitations. ${ }^{27}$ The wire recorder brought on the Arnhem Land Expedition, supplied by the Film Division, failed at the first camp, near Umbakumba on the coast of Groote Eylandt in east Arnhem Land, but not before Mountford was able to record a number of ceremonial songs. From these recordings, Mountford would publish a set of three 78rpm discs of Groote Eylandt songs (disc serial numbers PRX271214), one disc of songs recorded at Port Darwin in the weeks before the Arnhem Land Expedition (PRX2715), and two discs entitled Oenpelli Aboriginal Songs (PRX2716-17), although these last recordings were not made by him. ${ }^{28}$

Meeting with the Arnhem Land Expedition at Oenpelli for two weeks, were radio producer Colin Simpson of the Australian Broadcasting Commission (now Australian Broadcasting Corporation, ABC) with technical officer Ray Giles of the Post-Master General's department bearing another wire recorder and omni-directional dynamic microphone. Tasked with producing two radio

25 Martin Thomas, 'Expedition as Time Capsule: Introducing the American-Australian Scientific Expedition to Arnhem Land', in Exploring the Legacy of the 1948 Expedition, eds Margo Neale and Martin Thomas, (Canberra: ANU E Press, 2011), 2.

26 The dynamic microphone has a much more limited 'reach' than a condenser microphone, but does not require power and is much less susceptible to the effects of humidity. These factors would exclude the use of the much more sensitive condenser microphone from field work until more rugged FET-based condenser microphones were produced in the 1960s.

27 Of particular relevance is the effect of speed variations in the wire recorder and their impact on the reception and recognition of voices, important in repatriation efforts. See Anthony L. Jones, “'The Nostalgia of the Audio Souvenir": Technology limitations in the 1948 Arnhem Land field recordings of Colin Simpson', paper presented at the 11th Symposium on Indigenous Music and Dance, The Australian National University, Canberra, 2 December 2012.

28 Linda Barwick and Allan Marett, 'Aural Snapshots of Musical Life: The 1948 Recordings', in Exploring the Legacy of the 1948 Arnhem Land Expedition, eds Martin Thomas and Margo Neale (Canberra: ANU E Press, 2011), 357. 
documentaries for the $\mathrm{ABC},{ }^{29}$ Simpson and Giles recorded many traditional songs and ceremonies, the sound of morning birds on the lake at Oenpelli, and a wild buffalo hunt. After leaving the Arnhem Land Expedition, Simpson and Giles continued on to Delissaville (now Belyuen), and then Melville Island off the northern coast of Arnhem Land to make more recordings for the planned radio documentaries. These recordings by Simpson and Giles were published as a twelve-disc set of 78rpm discs under the title Aboriginal Music from the Northern Territory of Australia, 1948, with Annotations by Professor A. P. Elkin (disc serial numbers PRX2645-52 and PRX2708-11). ${ }^{30}$ A number of the recordings made in Oenpelli from this set were given to Mountford in an abbreviated form, and it was these that Mountford published as Oenpelli Aboriginal Songs under his own name.

Because of the failure of Mountford's wire recorder at the first camp on Groote Eylandt, no audio recordings were made at Yirrkala, which was the site of the second camp for the expedition and the subject of one of the documentary films, which would be produced. No field recordings of traditional song were carried out at Yirrkala until those of Richard A. Waterman in 1952.

Before the Arnhem Land Expedition, Mountford had proposed the production of five sound films. At the conclusion of the Arnhem Land Expedition after nine months of field work, with 'several miles of colour film on aboriginal life and natural history' to work with, Mountford proposed a new ambitious plan for nine films to be collated from the Arnhem Land Expedition footage. ${ }^{31}$ The Film Division was concerned at the potential cost of production of a series of nine films. They also considered that each of the proposed films would not of themselves hold enough interest for their potential audience. After a screening of rough cuts of the nine films on 29 September 1949, it was decided to reduce the series to three sound films for public exhibition, to be called Arnhem Land (incorporating scenes from the three different camps), Birds and Billabongs (filmed at Oenpelli), and Aborigines of the Seacoast (about the people of Yirrkala), with an additional silent film on the Arawaitja ceremony of Groote Eylandt and other unused source footage for Mountford's use in lecture tours. ${ }^{32}$ Since Mountford's death in 1976, these have been held at the Australian Institute for Aboriginal and Torres Strait Islander Studies in Canberra.

\footnotetext{
29 Tony MacGregor, 'Birds on the Wire: Wild, sound, informal speech and the emergence of the radio documentary', in Exploring the Legacy of the 1948 Arnhem Land Expedition, eds Martin Thomas and Margo Neale (Canberra: ANU E Press, 2011), 87.

30 Barwick and Marett, 'Aural Snapshots of Musical Life', 358.

31 Charles P. Mountford, Records of the American-Australian Scientific Expedition to Arnhem Land: Vol. 1 'art, myth and symbolism', ed. C. P. Mountford (Melbourne: Melbourne University Press, 1956), xxx.

32 'Memo to file (pencil)', in FPN160 Arnhem Land, SP1265/1 Part 2, National Archives of Australia (NAA), Sydney, 15 August 1949.
} 
The three sound films, produced for a general audience, would each include narration, limited sound effects (recorded separately), ${ }^{33}$ short fragments of field recordings of traditional song, and musical underscoring. Advice was sought from a number of scientists in the writing of the narration for the films on details of the flora and fauna to correct errors in the narration, yet the editing of the films was principally driven by perceived audience interest rather than striving for absolute accuracy. I now look at the process of scoring the films, and then discuss the influence of field-recorded traditional songs in the composition of the musical underscore.

\section{Scoring the Three Arnhem Land Expedition Documentary Films}

To write the musical underscore for the three sound films, Mountford and the DOI sought a composer with experience writing for film. A journalist friend of C. P. Mountford lived in the Sydney suburb of Mosman, next door to composers Alfred and Mirrie Hill. Alfred was at that time highly regarded, with an established international reputation as a composer of concert music and popular song. He had already gained some experience by this time in the writing of music for film, both in New Zealand and Australia, ${ }^{34}$ although he openly voiced disdain for the process and its inherent constraints - at the age of nearly eighty, he was not known as a patient man. ${ }^{35}$ Mirrie, twenty years his junior, was a well-regarded composer, but at that time lacked the extensive experience or the international renown of her husband.

Mountford arranged a meeting with Alfred Hill with the aim of commissioning him to write the scores for the Arnhem Land Expedition films. ${ }^{36}$ Mirrie Hill reported a conversation between the two men in two interviews recorded in 1982 and 1975.

[Alfred] invited Mr Mountford to come up [to our home] ... and $\mathrm{Mr}$ Mountford said to Alfred he would like him to write the background music for these three films. Without Alfred even asking me, he said "Well, I'll write two ... and she can write the other one!". Of course, you know who "she" was!" Well, I'd never written background music in my life! ${ }^{37}$

33 These included the ambient recordings of Simpson and Giles of birds on the billabong at Oenpelli, as well as other sounds such as waves lapping, children laughing, and so on.

34 Peter Limbrick, Making Settler Cinemas, 153.

35 Hill, Mirrie, 'On Music: Mirrie Hill Interviewed by James Murdoch' (South Melbourne: AFI Distribution

Ltd, 1982), henceforth Murdoch Interview.

36 The exact date of the first meeting is not known, but was most likely early in August 1949.

37 Murdoch Interview. 
Alfred was asked to write the music for the films. And Alfred hated writing commissions - he didn't like to have to do a certain thing in a certain time. And I persuaded him to do them. ${ }^{38}$

After that meeting between the Hills and Mountford, matters were discussed amongst the production staff of the Film Division. A handwritten note in the correspondence folder for the film Arnhem Land at the National Archives of Australia reads:

Arnhem Land - 15/8/49

Mountford talked to Hill — Alfred Hill — would like him to do music for these films.

Get aboriginal songs on to soft discs for Hill's guidance - will give 20/30 playings — [Mountford?] now in Adelaide with Bishop.

About 10 or 12 records - about 10/- each

Dept going to make hard recordings of all the songs. ${ }^{39}$

The particular custom 'soft discs' cut for the Hills have not yet been found, if indeed they still survive. It is possible that the Film Division did not have these 'soft discs' made up, but instead opted to purchase an existing set. If so, they might have used the twelve-disc set recorded by Simpson and Giles to which I have already referred. It is more likely, however, that Mountford would have seen to it that Mirrie and Alfred were supplied with his own complete sixdisc set described above, including the two discs of abbreviated material that had been recorded by Simpson and Giles. In the Mountford-Sheard collection held by the State Library of South Australia, there is notice of receipt of an order for six custom discs (five double-sided and one single-sided) from the EMI company, dated 24th January, 1950 - the six-disc set mentioned above. ${ }^{40}$ It is not known if this set of six discs was intended for the Hills - this order was placed about four months after their first meeting with Mountford. Some of the songs released as part of this set correspond to those transcriptions included in the Hills' notebooks.

In preparation for the writing of musical underscore for the three films, Mirrie and Alfred Hill both filled several music manuscript books with sketches for music that would go into the scores for the films, transcriptions from the field recordings of traditional song, and ideas for other works such as Mirrie's

38 De Berg Interview.

39 'Memo to file (pencil)', FPN160 Arnhem Land, SP1265/1 Part 2, NAA, Sydney, 15 August 1949.

40 R. V. Southey to C. P. Moutford, Mountford-Sheard Collection, PRG 1218/28/8 document 10, State Library of South Australia (SLSA), Adelaide, 24 January 1950. 
Symphony in A (Arnhem Land) (1954) (hereafter, the Symphony). ${ }^{41}$ Also held in the Hill family collection of the State Library of NSW with these manuscript books of Mirrie's, is a set of fully scored sketches for the Aborigines of the Seacoast (hereafter, Seacoast) music and a shortscore for both Arnhem Land, and for Birds and Billabongs. ${ }^{42}$ The final orchestral manuscripts and instrumental parts used for the recording of the three film scores are held at the National Archives of Australia in their Film Australia music collection. ${ }^{43}$ Access to the film Arnhem Land is restricted because of its inclusion of a sacred Ubar burial ceremony, featuring the balnooknook drum, and I have thus not been able to view this film. Birds and Billabongs is freely available for viewing by the public, but includes no reference to Aboriginal people or culture. As far as I can determine, there is no influence of Aboriginal song in the composition of the underscore for this film. The third film, Seacoast, is held in its original form as a preservation copy not available for viewing, but the version widely distributed and available for public viewing is a re-edit of the film created in 1973, for which a new narration was added, the music was rerecorded, and the underscore edited around the new narration.

In an interview, Mirrie Hill describes how she undertook the task of making transcriptions from the field recordings for both her and Alfred Hill's score writing. Mirrie described the process:

Mr Mountford lent us a lot [of recordings] and gave us some ... I've got some here ... to get into the mood of their singing. Well, I found out you couldn't take it down in our scale ... it was impossible. You could take down the rhythm in time, by turning it on and turning it off. But, what they sang, it wasn't in our scale. But I took some down as well as I could, and certainly got the rhythms, and the idea and the shape of the melodies. And it was from that, that I did my lot and Alfred did his.

In the same interview, Mirrie describes learning the process of scoring for film on the job, working out all the timings for the music in the three films.

I found that I had to time everything, and sometimes it was only seconds. Well, it's very hard if you have six seconds to write the background music to fit those six seconds of acting. And it was the timing... I think

\footnotetext{
41 Mirrie Hill, 'Symphony in A (Arnhem Land)', MUS Symphony Australia Collection, A/C HIL-M 31, National Library of Australia (NLA), Canberra, 1954.

42 A shortscore indicates the harmonic breakdown of the music on two-staff systems to be played on a piano. It might have annotations giving a rough idea of instrumentation, but is not complete. 'II - AH Music manuscripts, IV - AH Music manuscripts collected, VII - MH Music manuscripts \& IX - MH Music manuscripts', Hill Family Collection, MLMSS 6357, State Library of NSW (SLNSW).

43 Alfred Hill, 'Arnhem Land' [Music score] Arnhem Land, FPN160, C4482, NAA, Sydney, 1950; Mirrie Hill, 'Aborigines of the Seacoast' [Music score] Aborigines of the Seacoast, FPN26, C4482, NAA, Sydney, 1950; Alfred Hill, 'Birds and Billabongs' [Music score] Birds and Billabongs, FPN350, C4482, NAA, Sydney, 1950.
} 
I borrowed a stopwatch from somebody. I had to work this all out in seconds for Alfred — he wouldn't be bothered. And finally we got to it. $^{44}$

Working out the timings for each individual music cue was carried out at the DOI facility in Burwood, requiring the repeated viewing of the film with a stopwatch. With those timings and discussions with the producers about where music would sit and what kind of moods it might convey (all undocumented), Alfred and Mirrie Hill could then carry out the composition of the scores. ${ }^{45}$

The music for all three films was originally recorded in one mammoth session on Saturday 29 April 1950. To keep within a budget, both composers wrote for the same ensemble of instruments, except that Alfred's scores employed one extra instrument, an oboe. The total forty-five minutes of music for the three films was composed for a moderately large ensemble of flute, oboe, clarinet in A, bassoon, harp, percussion and strings - fourteen players in total. The size of the ensemble and extent of the music was a cause for some internal concern within the Film Division, finally resolved by a memorandum of 30 May 1950 recommending that Alfred Hill's fee be increased to $£ 150$ to allow for more players and more music than set out in the initial contract. ${ }^{46}$

The choice of instruments is not especially unusual for a documentary score of the period, with instrumentation normally derived from the symphony orchestra, but the inclusion of harp is particularly notable. In Alfred Hill's scores, the harp is used to add stereotypical flourish and grandeur, whereas Mirrie Hill's uses of the harp, with gentle arpeggios and simple melodies, alludes to a child-like innocence. No Aboriginal instruments are incorporated, but both Alfred and Mirrie use clave to emulate clap-sticks, and imitate the sound of the didjeridu with double bass or bassoon. Both Seacoast and Arnhem Land incorporate traditional song as source material to influence the composition of the underscore as well as featuring field recordings of songs in the soundtrack for the films.

I will now look at how Mirrie and Alfred Hill treated traditional Aboriginal song as source material in the scores to Aborigines of the Seacoast, and Arnhem Land.

\footnotetext{
44 Murdoch Interview.

45 It is usual practice for the underscore for a film to be written after the film is edited and all other sound elements are complete and it is a reasonable assumption that this is the case for these films because of the presence of traditional song as both an excerpt of field recording in the film soundtrack and as an influence for the writing of the underscore.

46 Stanley Hawes, Producer-in-Chief, Film Division 'Memorandum to Kevin Murphy, Director, ANIB', Arnhem Land FPN160, SP1265/1 Part 1, NAA, Sydney, 30 May 1950.
} 


\section{The Score for Aborigines of the Seacoast}

Mirrie Hill's sketches for the Seacoast score do not clearly indicate sources, although it seems most likely that all the traditional song material was derived from the six-disc set published under Mountford's name, as described above. Clues can be surmised from the composer sketchbooks. ${ }^{47}$ In any case, because no field recordings had been possible at Yirrkala, the songs included had to have come from another place, most likely from the field recordings at Groote Eylandt, Oenpelli or Port Darwin. None of the traditional music, whether appearing in the film as field recordings or as influence in the composition of the underscore, comes from Yirrkala. As these other songs come from quite different language groups, the use of these songs from out of Country is as incongruous as, say, a Thai song used to represent Vietnamese people.

There are eight identifiable themes that appear in the Seacoast music. Some of the themes undergo variation and development, and at a number of points in the music there is a blending of themes as one transforms into another. Of these eight themes, two can be identified as deriving from Aboriginal song. These two themes are given in an abbreviated form in Figures 1 and 2 .

The first of these is annotated in a later sketchbook of Aboriginal themes for Mirrie Hill's Symphony in A (Arnhem Land) with a reference to a recording identified as 'Cut 1 , Song 59, no. 24 '. ${ }^{48}$ The numbering system appears to relate to an annotated list to accompany the six-disc set, possibly written by Mountford (hereafter, Notes).$^{49}$ From these Notes, this song is indicated as 'Song (Unidentified)' on side B of the disc PX.2716. The same melody was also used for a later piano dance piece that Mirrie Hill wrote in 1951 for Beth Dean, as Dance of the Brolgas, and as we shall see the melody is also used by Alfred in his score for Arnhem Land..$^{50}$ Appearing several times through the underscore of Seacoast, the first iteration of the melody features a drone bass to emulate didjeridu, and clave keeping a regular stick pattern. This first appearance, originally playing under the opening titles for the film, is a forceful and fierce statement, done perhaps to give a dramatic opening to the film and denote the importance of the subject matter. Subsequent iterations of the same melody are presented in a much more gentle style without the constant drone. The contour of the melody

\footnotetext{
47 Mirrie Hill, 'Sketchbook "Aborigines of Arnhem Land"', Hill Family Collection, MLMSS 6357, VII - MH Music manuscripts, SLNSW, Sydney.

48 Mirrie Hill 'Sketchbook "Particulars of Aboriginal Themes - Arnhem Land Symph"', Hill Family Collection, MLMSS 6357, VII - MH Music manuscripts, SLNSW, Sydney.

49 C. P. Moutford, 'National Geographic Society and Australian Government Expedition to Arnhem Land, 1948: Aboriginal songs recorded by Charles P. Mountford', Mountford-Sheard Collection, PRG 1218/28/8, SLSA, Adelaide. The Hills may have been given a copy of this list, or the data may have been written on the disc labels.

50 Beth Dean and Victor Carrell, 'Concert Programme', Manuscript music of Mirrie Hill, Bib ID. 4934645, NLA, Canberra, 31 August 1950.
} 
is notable for the 'tumbling strain' which Mirrie Hill had identified in many of the field recordings of Aboriginal songs that she was presented with: 'there seems to be a trend to start the songs in a higher way and then come down, but not low to go up'. ${ }^{51}$

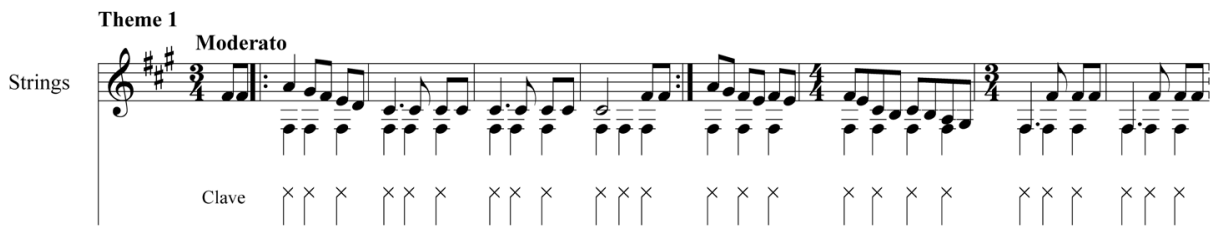

Figure 1: Mirrie Hill, opening theme for Aborigines of the Seacoast, derived from an as yet unidentified Aboriginal song.

Source: Author's reduction of the score.

The theme in Figure 2 underscores a group of children playing on the beach, and turtle hunters in a canoe. It can be identified as derived from one of the songs included in the field recordings made by Simpson and Giles and in Mountford's six-disc set in an abbreviated form. The theme also appears in sketches for the Symphony annotated as 'No. 53' and as 'Winbalung song'. Barwick and Marett believe this to be a mis-hearing of Gunbalang, a language from the coast to the north-west of Oenpelli, near Maningrida, and is listed in their summary of Simpson's recordings as 'Gunbalang [Kun-barlang] sweetheart song' ${ }^{52}$ The Gunbalang song is featured twice in the 1973 version of the film, at the beginning under the opening titles, and near the end accompanying images of children dancing and playing instruments. In the original version, the song appears only at the end of the film, and the opening titles are underscored by Mirrie Hill's theme given at Figure 1.

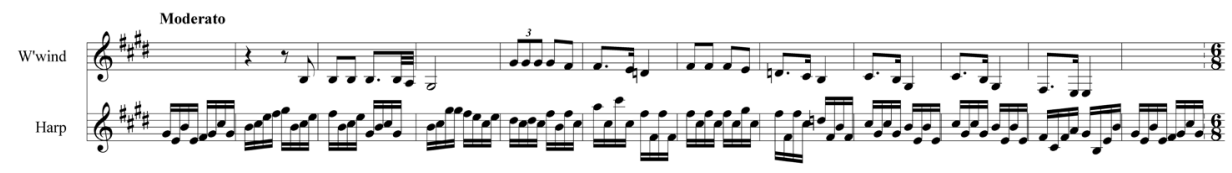

Figure 2: Mirrie Hill, theme for Aborigines of the Seacoast, derived from Gunbalang 'Sweetheart'.

Source: Author's reduction of the score.

51 Murdoch Interview.

52 Barwick and Marett, 'Aural Snapshots of Musical Life', 359. 
Technical limitations of the audio recording equipment used in the Arnhem Land Expedition, with the field recordings originally made with the wire recorder then transferred to 78rpm disc, created a speed inconsistency between the recording and the playback. This has two consequences: the pitch is raised for most of the recordings by a variable amount - for this song, approximately two semi-tones - and the formants of the voices are significantly raised, making the adult singers sound more like youths. Towards the end of the film, when we hear the song, it is played underneath images of young children on the beach at Yirrkala playing instruments and dancing.

The song is in a language from Maningrida and was recorded at Oenpelli, ${ }^{53}$ both several hundreds of kilometres away from Yirrkala. Additionally, an adult love song is presented as a song performed by children. As this raised-pitch version is the way the song was presented to Mirrie Hill, it is perhaps not surprising that she might have considered it a children's song, and this appears to have affected her choice of instrumentation for the film score as well as the approaches taken in the treatment of the melody in the score.

To compare her melody with the song of the field recording, it might not be immediately apparent that her composition is derived from an Aboriginal song. She has dramatically slowed down the melody, lengthened the gaps between phrases, transposed it into different keys, opted not to use a supporting drone (supplied in the original by didjeridu), and underlaid it with a changing harmonic structure. Additionally, it is her version of the melody which is presented first in the original version of the film and the field recording does not appear until nearly five minutes after Hill's version ends. In a re-edit of the film made in 1973, the version widely available for viewing in Australia, the field recording features under the opening titles, Hill's underscore version commences seven minutes after the field recording fades. The average viewer of the film, with their primary focus on the image rather than the music, is not likely to be aware that this melody, which Hill was evidently so taken with, actually derives from the field recording of an Aboriginal song. Hill passes the melody through a series of variations of texture, harmony and instrumentation, so that this one theme occupies more than one quarter of her entire underscore for the film. As the transcription of the field recording in her sketchbook for the Symphony suggests, Hill later reused the melody as the basis of the second movement of the Symphony, there played even slower.

By the sound of other themes in the score to Seacoast, it is possible that some are influenced by the traditional songs, however, no direct links have been determined. In the theme shown in Figure 3, it appears that Mirrie has conjoined her experience of hearing the field recordings with representations of 'primitive

53 Linda Barwick identified the origins of this song, personal communication, 21 February 2013. 
people' of the type heard in the music of Hollywood up to that time, as clearly expounded by Mark Slobin in his discussion of the music of Max Steiner. ${ }^{54}$ Placed in the film under images of children playing, the theme of Figure 3 has a pulsing tetratonic melody with short repeated melodic cells driven by a constant stick beat, reminiscent of the stereotypical representation of the music of North American First Nations peoples elucidated by both Gorbman and Pisani. ${ }^{55}$ Alfred and Mirrie Hill might not have had any experience of Aboriginal music to that time, and it is reasonable therefore to consider that their perception of "primitive music' might be drawn from the musical representations of Hollywood.

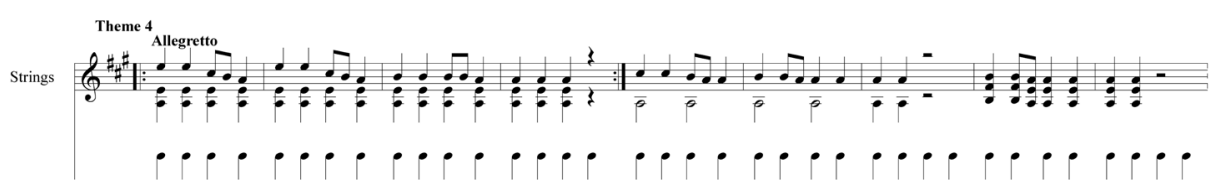

Figure 3: Mirrie Hill, theme for Aborigines of the Seacoast, most likely not derived from an Aboriginal song.

Source: Author's reduction of the score.

There are others of the field recordings that Mirrie would later use in her Symphony and other works, including the 'Song of the Jungle Fowl', which in her transcription Mirrie indicates as 'not secret'. It is in fact part of what Mountford misnamed the 'Arawaltja' ceremony ${ }^{56}$ of Umbakumba on Groote Eylandt and is restricted for audition only by initiated men. ${ }^{57}$ The Notes accompanying the recordings do not mention the secret nature of the song.

\section{The Score for Arnhem Land}

This film is restricted from public access because of the inclusion of an Ubar sacred burial ceremony, and no separate recording of the music has yet been found. Working from the shortscore held in the Hill collection of the State

\footnotetext{
54 Mark Slobin, 'The Steiner Superculture', in Global Soundtracks: Worlds of film music, ed. Mark Slobin, (Middleton: Wesleyan University Press, 2008), 3-35.

55 For a full discussion and examples of European renderings of music of First Nations people of North America, see Michael V. Pisani, Imagining Native America in Music, 292-329; Claudia Gorbman, 'Drums Along the LA River: Scoring the Indian', in Cinema and the Sound of Music: Proceedings from the 2nd Cinesonic Conference, ed. Phillip Brophy (Sydney: Australian Film TV \& Radio School, 2000), 97-116.

56 Martin Thomas, 'Unpacking the Testimony of Gerald Blitner: Cross-cultural brokerage and the Arnhem Land Expedition', in Exploring the Legacy of the 1948 Arnhem Land Expedition, eds Martin Thomas and Margo Neale (Canberra: ANU E Press, 2011), 398.

57 Alice M. Moyle, Handlist of Field Collections of Recorded Music in Australia and the Torres Strait: Occasional papers in Aboriginal studies (Canberra: Australian Institute of Aboriginal Studies, 1966), 28.
} 
Library of NSW, evidence of two Aboriginal songs can be seen. ${ }^{58}$ An inscription on the cover of the orchestral score notes 'The Native Tunes used were collected by C. P. Mountford'.$^{59}$ The score opens and closes with a strong imperial march in 5/4 time (see Figure 4). A transcription of the original field recording in Alfred's hand is available in another sketchbook, given in Figure 5-described as 'Cut 1 Song 73 Tjarada song Delissaville' recorded by Simpson and Giles at Delissaville. ${ }^{60}$ In the Notes, the song is given the number fifty-two and is the second cut on Side B of the disc PRX.2715. The song, with voices accompanied by a four-out-of-five-beat stick pattern, is sung in its original form by both male and female voices. Alfred later adapted his arrangement of the song into the third movement of his Australia Symphony in B minor (1951). ${ }^{61}$ Alfred's rendering of the melody is grandiose and quite overbearing, distinctly at odds with the sound of the song in the field recording.

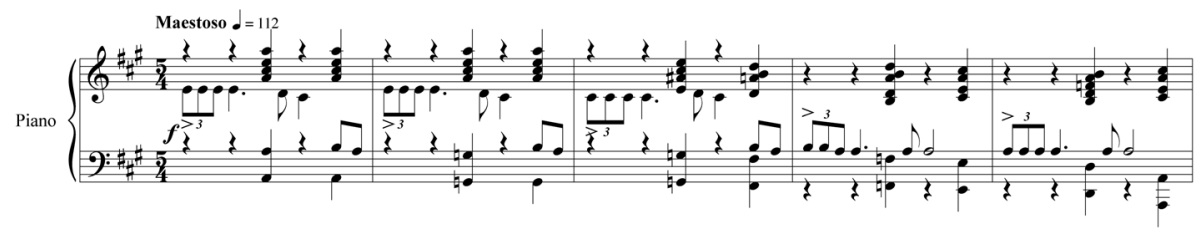

\section{Figure 4: Alfred Hill, opening and closing theme from Arnhem Land, derived from a Tjarada song collected at Delissaville.}

Source: Author's reduction of the score.

The second Aboriginal song that Alfred used as source material in his score for Arnhem Land is one that Mirrie also employed in Aborigines of the Seacoast, listed in the six-disc set only as 'Song (Unidentified)', as indicated above. A transcription from the field recording in Alfred's hand is in his sketches for the Arnhem Land score. A shortscore reduction of Alfred's rendering of the melody is given in Figure 6. If, as she has suggested, Mirrie Hill did all the transcribing of the songs from record, then Alfred's sketch for this song must be an adaptation from Mirrie's transcription. Compare this with Mirrie Hill's use of the same song in Figure 1. In the film Arnhem Land, this music accompanies the entrance of a group of Aboriginal men about to perform the Ubar ceremony. Alfred's setting of the melody is suitably solemn, given the occasion-quite different to Mirrie Hill's multiple settings of the same melody.

58 Alfred Hill, 'Arnhem Land' [music shortscore], Hill Family Collection, MLMSS 6357, II - AH Music manuscripts and IV - AH Music manuscripts collected, SLNSW, Sydney.

59 Alfred Hill, 'Arnhem Land' [Music score], Arnhem Land, FPN160, C4482, NAA, Sydney, 1950.

60 Barwick and Marett, 'Aural Snapshots of Musical Life', 359.

61 Andrew D. McCredie, 'Alfred Hill (1870-1960): Leipzig backgrounds and models and their significance for the later instrumental music (1920-1960)', in One Hand on the Manuscript: Music in Australian cultural history 1930-1960, eds Nicholas Brown, Peter Campbell, Robyn Holmes, Peter Read and Larry Sitsky (Canberra: The Humanities Research Centre, Australian National University, 1995), 30. 


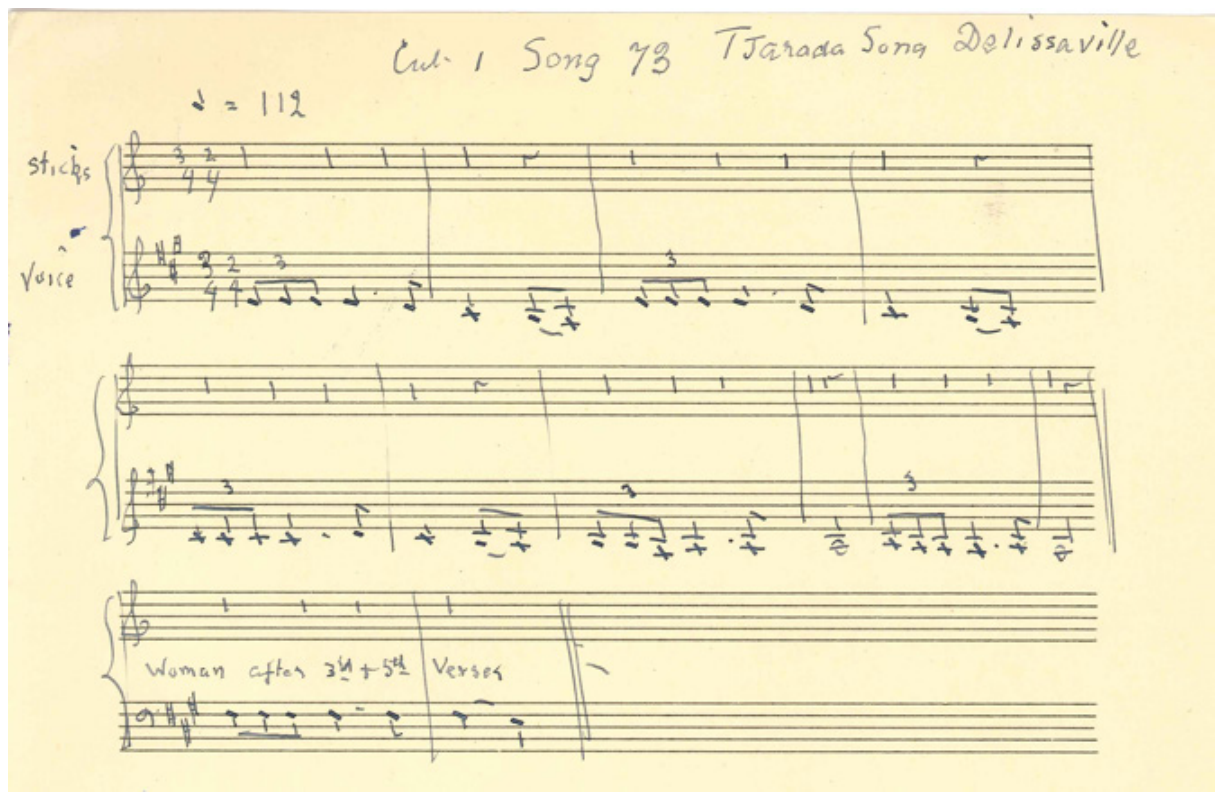

Figure 5: Alfred Hill, transcription of a Tjarada song, used in the score to Arnhem Land.

Source: Arnhem Land (sketchbook), in Hill family - Alfred Hill - music manuscripts and associated papers, 1887-1960, F. Motion Picture Music, call no. MLMSS 6357/22-23, SLNSW. Used with permission of the Estate of Mirrie Hill.

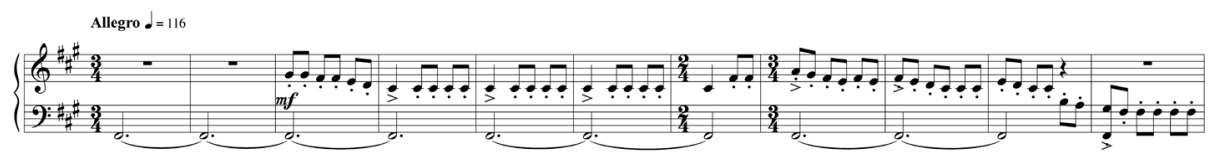

Figure 6: Alfred Hill, shortscore theme for the Ubar ceremony, the same song used by Mirrie Hill, shown in Figure 1.

Source: Author's reduction of the score.

\section{Reconfiguring the DOI Documentaries}

In 1950, magnetic tape was not yet available as a recording medium - the standard technology for recording was the optical sound track of film. For documentary films such as these, standard practice was to record the narration, sound effects and music onto separate synchronised film stock, then make a final mix for combination with the visuals. This allowed for replacement of the 
narration for non-English versions of a film for overseas markets. ${ }^{62}$ The quality of optical soundtracks was quite poor, with limited frequency response and dynamic range, and vulnerability to damage from dust and scratches in the process of projection. Because the Arnhem Land Expedition films continued to generate a lot of interest many years after their initial production, an opportunity was sought to upgrade the quality of the soundtrack by using the medium of magnetic tape.

Over the two years from 1973 to 1974, the newly-formed Film Australia made a decision to modify a number of their earlier documentaries in their acquired catalogue to reflect the developing public awareness of and respect for Aboriginal culture. ${ }^{63}$ These include the two earlier Mountford films, Walkabout (1940) and Tjurunga (1942), which were edited into one film under the title of Walkabout 1974, removing footage depicting secret/sacred ceremonies but keeping the original narration by C. P. Mountford. The film Namatjira, the Painter (1946) was significantly re-edited and a new narration written to show famed artist Albert Namatjira in a much-less paternalistic light than the earlier version of the film had done. The overly-huge Mackerras score was replaced with production music - guitar and harmonica - inoffensive and unobtrusive. ${ }^{64}$

As part of these changes, the scores to two of the Arnhem Land Expedition films were re-recorded by James McCarthy. This new recording, on magnetic tape, was far superior in quality to the original recording. Aborigines of the Seacoast, portraying the idyllic and isolated lives of the people on an 'untouched' stretch of east Arnhem Land coast, was reconfigured with a new narration changing the viewpoint of the film to that of a time-capsule of a lost era. Ten years after the Arnhem Land Expedition, the area featured in the film, Yirrkala, would be changed forever by the construction of a bauxite mining and aluminium smelting and shipping facility. In its reconfigured state, the film carries an overarching sense of melancholy, emotionally intensified (unintentionally) by Mirrie Hill's melodic and very personal composition style. The re-recorded music score was later included on a CD compiled by McCarthy for the Anthology of Australian Music on Disc series produced by the Canberra School of Music. ${ }^{65}$ Taking advantage of the opportunity with the ensemble of performers in the studio, McCarthy also re-recorded the score to Birds and Billabongs, although the audio for the film has not been redone and the re-recorded music has not been included in other media.

62 James McCarthy, personal communication, 17 February 2013.

63 ibid.

64 Efforts are now underway to prepare Mackerras' original score for concert performance as a representation of his early-career composition.

65 James McCarthy is compiling an annotated catalogue of all the music scores to the Film Australia collection. 
Why the film Arnhem Land was not re-edited with these other early Film Division documentaries is not yet known. Despite the re-recording of the music, the film Birds and Billabongs, was also not re-edited, but as the film did not include any reference to Aboriginal people or culture there was no sensitive material to cause offence and the film remains in wide distribution in its original state.

\section{Reflections on the Circulation of Song into New Compositions}

In this final section, I employ a number of analytical frameworks to aid the discussion of recontexualising traditional song into the scores for these documentary films. Ownership of the Arnhem Land Expedition field recordings, and through them the songs, is a contested space. Mirrie and Alfred Hill both credited Mountford as a co-composer for each of their film scores, drawing inspiration from the field recordings of traditional Aboriginal song. There was no acknowledgement of the traditional owners/composers of the songs, the originating locations of the songs, or even that some of the field recordings were carried out by Simpson and Giles. It is most probable that Mirrie and Alfred Hill were not aware that the Oenpelli field recordings were not recorded by Mountford. It seems that the secret/sacred nature of some of the material, particularly several of the songs Mountford recorded on Groote Eylandt, was not conveyed to them. In Mirrie's sketches, she has annotated as 'not secret' her transcription of the 'Song of the Jungle Fowl', ${ }^{66}$ which became an important theme in her Symphony. If the secret/sacred nature of some of the field recordings was discussed, she or Mountford were mistaken in identifying this song as suitable for public use. The Notes do not annotate any songs in the six-disc set as secret, although some songs include 'secret names' for animals, and other songs are listed as 'non-secret'.

Mountford was grateful for Alfred and Mirrie Hill's ongoing support and public acknowledgement of his contribution to their work. A handwritten letter from Mountford to them reads:

Dear Mr \& Mrs Hill 13.5.51

I was ever so pleased to get your letter a few weeks ago and to know that you have been able to make use of my recordings ... I must thank both

66 Found on side two, cut number two of disc PRX-2712, Groote Eylandt songs. 
of you for the full credit you have given me in every interview. This is valuable because it makes a few people realise that what I have done, in my limited way, in recording Aboriginal songs is of some use. ${ }^{67}$

A letter in the Arnhem Land correspondence file from 1956 states:

Further to your inquiry I now find that the records used by $\mathrm{Mr}$ Mountford were taken off wire recordings made by Colin Simpson.

I do not know the details of the arrangements made during 1948 between Mr Mountford and Mr Simpson, but the recordings are listed by the A.B.C. as belonging to Colin.

The set, consisting of 12 double sided records, can be ordered from the A.B.C. Sydney at a cost of $£ 6.0$. 0 per set. ${ }^{68}$

What are we to make of Alfred and Mirrie Hill's adaptation of Aboriginal song in the context of newly-composed music as underscore to these films? Commenting on the Jindyworobak poets' use of Aboriginal words and myths in the early twentieth century, David Symons defends their approach:

From today's standpoint this may be seen as a kind of cultural appropriation, as the Jindyworobak preoccupation with things Aboriginal was not primarily for the sake of Aboriginal culture itself, nor was it concerned with that culture's relationship with a white displacing culture. It was rather a means for the white Australian to achieve a similarly deep spiritual link with the unique Australian environment. However, in the Jindyworobak period, the concept of "cultural appropriation" would not have occurred to non-indigenous artists, and certainly not as an ethical issue. ${ }^{69}$

Gregg W. Howard's framework for engagement with recontextualised Aboriginal song may be a useful tool of analysis. Discussing the works of the composer Clive Douglas, Howard identifies three types of engagement:

1. The derived material may be so abstracted from its original form as to lose its recognisable identity.

2. In an attempt to accommodate this fact, the composer may contrive the musical expression to the extent that the derived material is caricature.

67 C. P. Mountford. 'Letter to Alfred and Mirrie Hill', Hill Family Collection, MLMSS 6357, VI - Mirrie Hill, personal papers, SLNSW, Sydney, 13 May 1951.

68 R. Edwards (for Producer-in-Chief, Stanley Hawes?), 'Letter to (Kevin Murphy?) Director, ANIB', Arnhem Land, FPN160, SP1265/1 Part 2, NAA, Sydney, 19 June 1956.

69 Symons, 'Jindyworobak Connection': 34. 
3. The material may be allowed to retain its recognisable identity and is 'framed' by rather than integrated into the musical fabric. ${ }^{70}$

For the underscore composition in the two documentary films, the traditional songs are taken from their instrumental, vocal, and extra-musical context. Their purpose and intention is altered, and the music abstracted to the point where it is difficult to identify their origins without recourse to analysis of the written scores and sketchbooks. Identification by ear requires focused attention on the score, not normally afforded in their context accompanying the films.

In Aborigines of the Seacoast, Mirrie Hill has incorporated traditional songs, selecting and processing the melodies of the songs in such a way that they become subsumed within her own compositional style. The melody given in Figure 3, which seems not to originate from a field recording in the six-disc set, appears to be Mirrie Hill's interpretation of an Aboriginal style interpolated with the 'primitive music' of Hollywood films, more in the category of a caricature. While her treatment of the 'Winbalung Sweetheart song' is skilful and appealing, accompanying images of children playing on the beach, her composition is far removed from the particulars and application of the original song. It is likely that the pitch alteration in the song and the positioning of the field recording in the film under images of children playing on the beach influenced her use and interpretation of the material. Mirrie Hill's treatment of the other song, annotated as 'Song (untitled)', sits less comfortably in its various settings, and becomes caricature, with the melodic contour constrained to a minor pentatonic scale, imitation of a didjeridu drone and constant click rhythm.

Alfred Hill's composition style was informed by a late-nineteenth century Germanic training, evident in his settings of the songs. The 'Song (untitled)' in his hands becomes slow, sombre and pompous, accompanying images of Aboriginal men walking onto a sacred space to conduct a burial ceremony. His setting of the Tjarada song transforms the song into a stately march in 5/4 with a grandiosity that would seem intended to welcome an imperial procession. The settings of both songs are so removed from the sound and intention of the traditional songs that they acquire the status of caricature. Neither Mirrie's nor Alfred's settings of Aboriginal song could be considered to allow the material to retain its identity as framed in Howard's third kind of engagement above.

A further framework might be pertinent to this consideration of the legacy of composers such as Mirrie and Alfred Hill. Discussing the recording of sounds particular to a place, R. Murray Schafer defined the term schizophonia as 'the

70 Gregg W. Howard, 'Clive Douglas (1903-1977),' in Australian Composition in the Twentieth Century, eds Frank Callaway and David Tunlet (Melbourne: Oxford University Press, 1978), 38, quoted in Symons, 'Jindyworobak Connection': 45. 
split between an original sound and its electro-acoustical transmission or reproduction'. ${ }^{71}$ Feld expands upon this notion in his discussion of traditional musics taken from their context and used in hybrid commodities created by the commercial music industry in the 'world music' phenomena of the 1980s and 1990s. Feld's voice was one of many questioning the role of the commercial music industry in hybrids such as those of rock artists Paul Simon and Peter Gabriel in the 1980s. Feld's own conundrum comes from his two positions as both an academic and as an active participant in the creation of 'transcultural record productions', ${ }^{72}$ with the Kaluli people of Bosavi in Papua New Guinea. While critical of massive international corporations drawing profits from the cultural capital of non-Western cultures through these hybrids, he is very conscious of his own actions in this regard. He highlights the primary argument in defence of these hybrids - that the criticism of these projects is less straightforward when some benefits can be seen to be returned to the source cultures.

In the instance of these film scores, there was no promise of extensive financial gain from the appropriation of traditional song either from the scores or the subsequent concert works, however, the use of the materials gave new impetus to the composing careers of both composers, and Mountford was a beneficiary through continuing association with them, as well as with the choreographer Beth Dean. The Hills' efforts could be considered to be comparable to those of the renowned and highly regarded watercolour artist Albert Namatjira, whose art offered a carefully controlled view of Aboriginal experience of Country through a Western idiom. Mirrie and Alfred Hill took elements of Aboriginal culture and re-presented them in a context palatable to a society for whom Aboriginal culture was quite alien, however, their presentation of elements of Aboriginal culture in a Western idiom is derived from their position outside the culture.

Cycles of culture turn slowly, fitfully. We must consider these efforts in the context of their times and see them as part of a continuum of growing understanding. As was, and still is, common practice in the writing of Western music drawing influence from other sources, both Mirrie and Alfred Hill in their different ways have taken the traditional source materials and integrated them into their own compositional practice, rendering them disconnected from the source materials. Both composers have used songs out of their normal context with little consideration of their place of origin. They have operated within their limited understanding and prejudices of Aboriginal culture. Their lack of understanding is indicative of a broader societal lack of engagement with

71 R. Murray Schafer, quoted in Steven Feld, 'From Schizophonia to Schismogenesis: The discourses and practices of world music and world beat', in The Traffic in Culture: Refiguring art and anthropology, eds George E. Marcus and Fred R. Myers (Berkeley: University of California Press, 1995), 97.

72 ibid. 
Aboriginal culture. Mark Slobin has written: 'every film is ethnographic, and every soundtrack acts like an ethnomusicologist' ${ }^{73}$ So it is with these films and these soundtracks - they allow us to take the temperature of the times.

The 'circulation' in the title of this book encourages the notion of a returning, but the processes described in this chapter have resulted in the mining of cultural capital in a unidirectional move into the dominant culture. Repatriation efforts on the traditional songs collected on this and other expeditions begin with the return of historical field recordings, and Brown, Campbell, and Treloyn demonstrate an ongoing engagement with cultures, ${ }^{74}$ being the mediators of change. ${ }^{75}$ To close the circle, these altered materials could be taken back to the originating communities. In the case of the music composed by Alfred and Mirrie Hill, that is a task which still remains to be done.

There exists still today somewhat of a 'musical tourist' approach to the incorporation of traditional song and instrumentation into contemporary composition $^{76}$ - the cultural conversation still flows mostly in one direction. It can be hoped that an awareness of these past attempts can help deepen an understanding of the impacts of misinterpretation and appropriation, and allow for genuine cultural exchange.

\section{Acknowledgements}

This research was made possible through the granting of a Scholars and Artists in Residence research fellowship with the National Film and Sound Archive (NFSA) in Canberra in 2011. Thanks especially to the NFSA's Vincent Plush, Jenny Gall, Graham Shirley, Matthew Davies, Christine Eccles, Kylie Doherty, Brenda Gifford and Gerry O'Neill. I am also grateful to the State Library of NSW, in particular Meredith Lawn; Film Australia; the National Archives, especially to Edmund Rutlidge; the National Library of Australia, particularly Robyn Holmes and volunteers; the State Library of South Australia; and the Australian Institute for Aboriginal and Torres Strait Islander studies, especially Grace Koch. Thanks to James McCarthy, Martin Thomas, Linda Barwick and Allan Marett for their time and sharing of knowledge. The chapter has benefitted directly from advice on drafts from Linda Barwick, Amanda Harris and two anonymous reviewers.

\footnotetext{
73 Mark Slobin, 'The Steiner Superculture', in Global Soundtracks: Worlds of film music, ed. Mark Slobin, (Middleton: Wesleyan University Press, 2008), 3-4.

74 See the chapters by Brown, Campbell and Treloyn, this volume.

75 See Harris' 'sixth period' in chapter 1 of this volume.

76 James McCarthy, personal communication, 17 February 2013.
} 


\section{References}

Barwick, Linda, and Allan Marett. 'Aural Snapshots of Musical Life: The 1948 recordings', in Exploring the Legacy of the 1948 Arnhem Land Expedition, eds Martin Thomas and Margo Neale (Canberra: ANU E Press, 2011), 355-76.

Blainey, Geoffrey. The Tyranny of Distance: How distance shaped Australia's history (Sydney: Macmillan, 2001).

Chion, Michel. Audio-Vision: Sound on screen, trans. Claudia Gorbman (New York: Columbia Unversity Press, 1994).

Chion, Michel. Film, a Sound Art, trans. Claudia Gorbman (New York: Columbia University Press, 2009).

Covell, Roger. Australia's Music: Themes for a new society (Melbourne: Sun Books, 1967).

Dunlop, Ian. 'Ethnographic Filmmaking in Australia: The first seventy years (1898-1968)', Studies in Visual Communication 9:1 (1983): 11-18.

Feld, Steven. 'From Schizophonia to Schismogenesis: The discourses and practices of world music and world beat', in The Traffic in Culture: Refiguring art and anthropology, eds George E. Marcus and Fred R. Myers (Berkeley: University of California Press, 1995), 96-126.

Flinn, Caryl. Strains of Utopia: Gender, nostalgia and Hollywood film music (Princeton: Princeton University Press, 1992).

Gorbman, Claudia. Unheard Melodies: Narrative film music (Bloomington: Indiana University Press, 1987).

Gorbman, Claudia. 'Drums Along the LA River: Scoring the Indian', in Cinema and the Sound of Music: Proceedings from the 2nd Cinesonic Conference 1999, ed. Phillip Brophy (Sydney: Australian Film TV and Radio School, 2000), 97-116.

Griffiths, Alison Margaret. Origins of Ethnographic Film (PhD, New York University, 1998).

Hill, Mirrie. 'On Music: Mirrie Hill Interviewed by James Murdoch' (South Melbourne: AFI Distribution Ltd, 1982).

Hill, Mirrie. 'Aborigines of the Seacoast', in Film Music of the 1960s: From the Film Australia collection, ed. James McCarthy, CSM 36, Anthology of Australian Music on Disc: Series 4 (Canberra: Canberra School of Music, 1999). 
Howard, Gregg W. 'Clive Douglas (1903-1977)', in Australian Composition in the Twentieth Century, eds Frank Callaway and David Tunley (Melbourne: Oxford University Press, 1978), 37-43.

Jones, Anthony L. "The Nostalgia of the Audio Souvenir": Technology limitations in the 1948 Arnhem Land field recordings of Colin Simpson', paper presented at the 11th Symposium on Indigenous Music and Dance, The Australian National University, Canberra, 2 December 2012.

Kalinak, Kathryn. Settling the Score: Music and the classical Hollywood film (Madison: University of Wisconsin Press, 1992).

Kassabian, Anahid. Hearing Film: Tracking identifications in contemporary Hollywood film music (New York: Routledge, 2001).

Limbrick, Peter. Making Settler Cinemas: Film and colonial encounters in the United States, Australia and New Zealand (New York: Palgrave Macmillan, 2010).

MacGregor, Tony. 'Birds on the Wire: Wild, sound, informal speech and the emergence of the radio documentary', in Exploring the Legacy of the 1948 Arnhem Land Expedition, eds Martin Thomas and Margo Neale (Canberra: ANU E Press, 2011), 87-111.

McCredie, Andrew D. 'Alfred Hill (1870-1960): Leipzig backgrounds and models and their significance for the later instrumental music (1920-1960)', in One Hand on the Manuscript: Music in Australian cultural history 1930-1960, eds Nicholas Brown, Peter Campbell, Robyn Holmes, Peter Read and Larry Sitsky (Canberra: The Humanities Research Centre, The Australian National University, 1995), 18-33.

Mercer, Christine. 'Henry Tate: Views on the artistic possibilities of Aboriginal music', in Encounters: Meetings in Australian music: Essays, images, interviews, eds Vincent Plush, Huib Schippers and Jocelyn Wolfe (Brisbane: Queensland Conservatorium Research Centre, 2005).

Mountford, Charles P. Aborigines of the Sea Coast. (Lindfield: Film Australia, 1951).

Mountford, Charles P. Records of the American-Australian Scientific Expedition to Arnhem Land: Vol. 1 'art, myth and symbolism', ed. C. P. Mountford (Melbourne: Melbourne University Press, 1956).

Moyle, Alice M. Handlist of Field Collections of Recorded Music in Australia and the Torres Strait: Occasional papers in Aboriginal studies (Canberra: Australian Institute of Aboriginal Studies, 1966). 
National Archives of Australia. 'Commonwealth Film Unit: Fact sheet 25', (2013), accessed 12 February 2013, http://www.naa.gov.au/collection/factsheets/fs25.aspx.

Pisani, Michael V. Imagining Native America in Music (New Haven: Yale University Press, 2005).

Reece, Bob. Daisy Bates: Grand dame of the desert, ed. Carol Natsis (Canberra: National Library of Australia, 2007).

Shirley, Graham, and Brian Adams. Australian Cinema: The first eighty years (Sydney: Currency Press, 1989).

Simpson, Colin. Adam in Ochre: Inside Aboriginal Australia (Sydney: Angus \& Robertson, 1951).

Slobin, Mark. 'The Steiner Superculture', in Global Soundtracks: Worlds of film music, ed. Mark Slobin (Middleton: Wesleyan University Press, 2008), 3-35.

Symons, David. 'The Jindyworobak Connection in Australian Music, c. 19401960', Context: Journal of music research 23 (2002): 33-47.

Thomas, Martin. 'A Short History of the 1948 Arnhem Land Expedition', Aboriginal History 34 (2010): 143-73.

Thomas, Martin. 'Unpacking the Testimony of Gerald Blitner: Cross-cultural brokerage and the Arnhem Land Expedition', in Exploring the Legacy of the 1948 Arnhem Land Expedition, eds Martin Thomas and Margo Neale (Canberra: ANU E Press, 2011), 377-401.

Thomas, Martin and Margo Neale, eds. Exploring the Legacy of the 1948 Expedition. (Canberra: ANU E Press, 2011). 
This text taken from Circulating Cultures: Exchanges of Australian Indigenous music, dance and media, edited by Amanda Harris, published 2014 by ANU Press, The Australian National University, Canberra, Australia. 